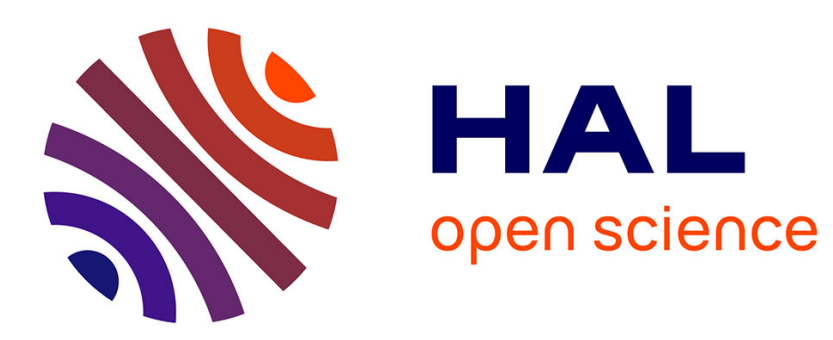

\title{
A Photo-Chemical Method for the Production of Olivine Nanoparticles as Cosmic Dust Analogues
}

\author{
Russell W. Saunders, John M.C. Plane
}

\section{To cite this version:}

Russell W. Saunders, John M.C. Plane. A Photo-Chemical Method for the Production of Olivine Nanoparticles as Cosmic Dust Analogues. Icarus, 2011, 212 (1), pp.373. 10.1016/j.icarus.2010.12.019 . hal-00725406

\section{HAL Id: hal-00725406 https://hal.science/hal-00725406}

Submitted on 26 Aug 2012

HAL is a multi-disciplinary open access archive for the deposit and dissemination of scientific research documents, whether they are published or not. The documents may come from teaching and research institutions in France or abroad, or from public or private research centers.
L'archive ouverte pluridisciplinaire HAL, est destinée au dépôt et à la diffusion de documents scientifiques de niveau recherche, publiés ou non, émanant des établissements d'enseignement et de recherche français ou étrangers, des laboratoires publics ou privés. 


\section{Accepted Manuscript}

A Photo-Chemical Method for the Production of Olivine Nanoparticles as Cosmic Dust Analogues

Russell W. Saunders, John M.C. Plane

PII:

S0019-1035(10)00487-2

DOI:

10.1016/j.icarus.2010.12.019

Reference:

YICAR 9670

To appear in:

Icarus

Received Date: $\quad 16$ August 2010

Revised Date: $\quad 24$ November 2010

Accepted Date: $\quad 18$ December 2010

Please cite this article as: Saunders, R.W., Plane, J.M.C., A Photo-Chemical Method for the Production of Olivine Nanoparticles as Cosmic Dust Analogues, Icarus (2010), doi: 10.1016/j.icarus.2010.12.019

This is a PDF file of an unedited manuscript that has been accepted for publication. As a service to our customers we are providing this early version of the manuscript. The manuscript will undergo copyediting, typesetting, and review of the resulting proof before it is published in its final form. Please note that during the production process errors may be discovered which could affect the content, and all legal disclaimers that apply to the journal pertain. 


\section{A Photo-Chemical Method for the Production of Olivine Nanoparticles \\ 2 as Cosmic Dust Analogues}

3 Russell W. Saunders and John M.C. Plane

4 School of Chemistry, University of Leeds, Leeds UK LS2 9JT

5 Corresponding author: John Plane - email: j.m.c.plane@leeds.ac.uk/Tel: $+44(0) 113$

6 38044/Fax: $+44(0) 1133436565$

8 Abstract

9 This paper describes a new experimental method to synthesise metal silicate particles in

10 the laboratory with compositions and structures which reflect those likely to form in

11 planetary atmospheres and in relatively cool regions of oxygen-rich stellar outflows. Fe-

$12 \mathrm{Mg}$-silicate nanoparticles of olivine composition were produced by the photo-oxidation

13 of a mixture of $\mathrm{Fe}(\mathrm{CO})_{5}, \mathrm{Mg}\left(\mathrm{OC}_{2} \mathrm{H}_{5}\right)_{2}$ and $\mathrm{Si}\left(\mathrm{OC}_{2} \mathrm{H}_{5}\right)_{4}$ vapours in the presence of $\mathrm{O}_{3}$ at

14 room temperature and atmospheric pressure. Transmission electron microscope $\mathrm{x}$-ray and

15 electron energy loss analysis of the particles from a number of experiments run with

16 different precursor vapour mixture ratios show that $\mathrm{Mg}_{2 x} \mathrm{Fe}_{2-2 x} \mathrm{SiO}_{4}$ particles can be

17 produced ranging from $x=0$ to 1 , where $x$ is linearly proportional to the ratio of

$18 \mathrm{Mg}\left(\mathrm{OC}_{2} \mathrm{H}_{5}\right)_{2} /\left(\mathrm{Fe}(\mathrm{CO})_{5}+\mathrm{Mg}\left(\mathrm{OC}_{2} \mathrm{H}_{5}\right)_{2}\right)$. Electronic structure calculations with hybrid

19 density functional/Hartree-Fock theory are then used to explore the pathways involved in

20 producing olivine particles from the $\mathrm{FeO}_{3}, \mathrm{MgO}_{3}$ and $\mathrm{SiO}_{2}$ produced from the photolysis

21 of the organometallic precursors in $\mathrm{O}_{3}$. These calculations indicate that highly exothermic

22 reactions lead to the formation of $\mathrm{Mg}_{2} \mathrm{SiO}_{4}, \mathrm{MgFeSiO}_{4}$ and $\mathrm{Fe}_{2} \mathrm{SiO}_{4}$ molecules, which 
23 then polymerize. An alternative pathway, also strongly favoured thermodynamically, is

24 the polymerization of $\mathrm{MgSiO}_{3}$ and $\mathrm{FeSiO}_{3}$ to form pyroxenes, which then undergo

25 structural rearrangement to olivine and silica phases. The implications for metal silicate

26 formation in planetary atmosphere and stellar outflows are then discussed.

\section{1. Introduction}

29 Speculation on the chemical composition of dust particles found in a variety of extra-

30 terrestrial environments (e.g. interstellar and circumstellar), backed by the large database

31 of optical measurements made over the past half century or so (see Whittet, 2003),

32 invariably identifies metal (primarily iron and magnesium) silicate compounds as a major

33 component (Rietmeijer, 2002; Draine, 2003; Henning, 2010). Indeed, the term

34 'astronomical silicate' has been coined for a general olivine $\left(\mathrm{Mg}_{2 x} \mathrm{Fe}_{2-2 x} \mathrm{SiO}_{4} ; x \sim 0.5\right)$

35 structure which provides a best-fit to certain features in the optical data (Draine and Lee,

36 1984). These dust particles are not only important in that they scatter, absorb and re-

37 radiate light, but also because they act as catalytic substrates for the uptake and reaction

38 of ambient gas-phase species, and hence are thought to be vital for the synthesis of

39 detected molecular species such as $\mathrm{H}_{2}$ and $\mathrm{CO}$ (Williams and Taylor, 1996).

40 Analysis of peak structure within the diagnostic Si-O bond vibrations at $\sim 10$ and 18

41 microns suggests a crystalline, Mg-rich $(x>0.5)$ nature for these mineral forms

42 (pyroxene and olivine) of dust in certain high temperature environments i.e. in proximity

43 to evolving stars (Gail and Sedlmayr, 1999) and also in comets and planetary nebulae

44 (Jäger et al. 1998). However, it has been reported that amorphous Fe-rich $(x<0.5)$ olivine

45 variations are dominant in the interstellar medium or ISM (Draine, 2003; Kemper et al., 
46 2004), with a significant proportion of such grains in the lowest density regions of the

47 ISM being less than $3 \mathrm{~nm}$ in size (Li and Draine, 2001).

48 It has long been suggested that nanoparticles of 'meteoric smoke' are formed in the upper

49 atmosphere of the Earth, as a result of meteor ablation and subsequent condensation of

50 gas-phase metal oxide and silicate species (Rosinski and Snow, 1961; Hunten et al.,

51 1980). Ablation modelling indicates that the majority of atoms/ions released into the

52 atmosphere from the parent meteoroid are (in approximately equivalent amounts) those of

53 iron, magnesium and silicon (Vondrak et al., 2008). Subsequent oxidation of these

54 species is then likely to initiate condensation of solid-phase silicaceous material (smoke

55 particles).

56 Such particles are predicted to be of the order of only a few nanometres in size and

57 consequently, proof of their existence through optical methods has to date been difficult

58 and largely inconclusive. Recent satellite-bound spectrometer measurements of high

59 altitude particle extinction seem to be the first to identify these tiny smoke particles

60 (Hervig et al., 2009), although compositional fitting of such data is reliant on refractive

61 index data available for a limited range of silicate materials prepared in the laboratory.

62 The interaction of meteoric smoke particles or MSPs with gases such as $\mathrm{H}_{2} \mathrm{O}$ and $\mathrm{H}_{2} \mathrm{SO}_{4}$

63 in the Earth's atmosphere has long been thought to play a role in such phenomena as high

64 altitude ice particle nucleation, leading to the related phenomena of noctilucent clouds

65 and polar mesosphere summer echoes (Rapp and Thomas, 2006), and the depletion of

66 acidic gases in the upper stratosphere (Turco et al., 1981). Clearly the precise nature of

67 such particle-vapour interactions will be strongly dependent on the particle composition.

68 The formation of meteoric smoke (and subsequent interaction with organic vapours) has 
69 recently been postulated to account for the observed 'detached' aerosol layer in Titan's

70 atmosphere (Lavvas et al., 2009). MSPs are also almost certainly the nuclei which form

$71 \mathrm{CO}_{2}$-ice clouds in the Mars mesosphere around $80 \mathrm{~km}$ (Montmessin et al., 2006). In the

72 ISM, dust particles play a crucial role, for example, in the synthesis of molecules through

73 heterogeneous chemistry (e.g. Williams and Hartquist, 1999).

74 The critical ingredients for the formation of such smoke and dust particles in the

75 terrestrial and other planetary atmospheres, and in favourable regions of the ISM (see the

76 review of Henning, 2010) such as, for example, the cooling outflows / circumstellar

77 envelopes of oxygen-rich asymptotic giant branch (AGB) stars (e.g. Gail and Sedlmayr,

78 1999; Gail, 2010), planetary nebulae (e.g. Gorny et al., 2010) or regions chemically

79 enriched by supernovae (e.g. Kotak et al., 2009), are (i) a source of metal and silicon

80 atoms, and (ii) an oxidising species to form the initial gas-phase metal oxide and silicon

81 oxide molecules. These can then react to form molecular silicate species (see section 3.2).

82 In planetary/satellite atmospheres where the atmospheric pressure is greater than about 1

$83 \mu$ bar, meteoric ablation occurs (e.g. McAuliffe and Christou, 2006; Kim et al., 2001; Ip,

84 1990; English et al., 1996; Molina-Cuberos et al., 2008; Pesnell and Grebowsky, 2000;

85 Whalley and Plane, 2010). The resulting metal and silicon atoms are then oxidized in the

86 presence of $\mathrm{O}_{3}$ and $\mathrm{O}_{2}$, which tend to be present at some level (e.g. Fast et al., 2009;

87 Migliorini et al., 2010; Noll et al., 1997; Hörst et al., 2008). In the ISM, the stellar

88 nucleosynthesis and ejection of metals such as Fe and $\mathrm{Mg}$ and of Si accompanied by the

89 presence of oxygen in the form of neutral and ionised forms or in volatile molecules or

90 ices (Jensen et al., 2008) will likewise be conducive to the formation of silicate species. 
91 The production of analogue materials for cosmic dust studies has utilised a number of

92 methods (reviewed by Colangeli et al., 2003) including room temperature sol-gel

93 preparations (Thompson et al., 1996; Jäger et al., 2003), melt quenching (Dorschner et

94 al., 1995), and vapour condensation methods such as laser ablation-condensation

95 (Brucato et al., 2002) and high temperature evaporation-condensation (Rietmeijer et al.,

96 1999; Nuth et al., 2000). The purpose of such laboratory techniques is not to replicate

97 directly the chemical or physical conditions in which particle formation can occur in the

98 Earth's atmosphere, other planetary atmospheres or the ISM, but to provide a way of

99 forming particles of realistic composition and structure for the subsequent study of their

100 physical and chemical properties under conditions appropriate for a targeted environment.

101 Sol-gel/melt quenching syntheses can produce amorphous pyroxene and olivine

102 compounds with mixed compositions, but the vapour condensation methods to date have

103 indicated that formation of mixed Mg-Fe silicate materials is not favoured. However,

104 more recent studies using the photo-oxidation of 'binary' mixtures of iron and silicon

105 precursor vapours at room temperature (Saunders and Plane, 2006; Kimura and Nuth,

106 2007) led to the preferential nucleation and subsequent growth of amorphous particles

107 with end-member olivine composition. To the best of our knowledge, there have, as yet,

108 been no reports of the formation of mixed-composition (Fe-Mg) olivine materials directly

109 from the gas-phase at low (room) temperature. This has important implications for

110 understanding dust compositions in lower temperature environments such as

111 planetary/satellite atmospheres and the ISM.

112 Our earlier study (Saunders and Plane, 2006) was aimed at synthesising and studying the

113 properties of nanomaterials as analogues of meteoric smoke particles or MSPs. This 
114 paper extends our investigations to a more realistic 'tertiary' vapour system, whereby a

115 mixture of iron, magnesium and silicon oxide vapours is generated, from which mixed

116 composition olivine nanoparticles are produced. Electron microscope x-ray analysis

117 (TEM-EDX) and electron energy loss spectroscopy (EELS) data from collected material

118 is used to show that (1) the final particle composition is homogeneous and (2), the

119 relative $\mathrm{Fe} / \mathrm{Mg}$ composition in the particles can be controlled quantitatively from $x=0-$

1201 by varying the relative flows of the organometallic precursors. To complement the

121 laboratory studies, we use electronic structure theory to identify likely molecular

122 structures and chemical pathways which result in the observed particle compositions.

\section{2. Experimental Methods}

125 An aerosol flow reactor system (cylindrical laminar flow glass cell fitted with a series of

126 quartz windows which act as photolysis ports) described in detail previously (Saunders

127 and Plane, 2006) was used for the nucleation and growth of refractory aerosol from the

128 photo-oxidation of mixed vapours of the precursors, iron pentacarbonyl $\left(\mathrm{Fe}(\mathrm{CO})_{5}\right.$,

$12999.999 \%$, Aldrich), magnesium ethoxide $\left(\mathrm{Mg}\left(\mathrm{OC}_{2} \mathrm{H}_{5}\right)_{2}, 98 \%\right.$, Aldrich) and tetraethyl

130 orthosilcate or TEOS $\left(\mathrm{Si}\left(\mathrm{OC}_{2} \mathrm{H}_{5}\right)_{4}, 98 \%\right.$, Aldrich), in $\mathrm{N}_{2}$ bath gas at $293 \mathrm{~K}$ and

131 atmospheric pressure. Photolysis of the precursor vapours was achieved using a broad-

132 band Xe arc lamp $(\lambda>300 \mathrm{~nm})$, whose beam was directed through the quartz cell

133 windows using a flat mirror, and attenuated using neutral density filters to achieve the

134 desired photolysis rate in the experiments. A total gas flow rate (precursors, $\mathrm{O}_{2}$ and $\mathrm{N}_{2}$

135 bath gas) of $600 \mathrm{~cm}^{3}$ per minute at STP was used in all experiments. Ozone $\left(10^{13}-10^{14}\right.$ 
$136 \mathrm{~cm}^{-3}$ ) was generated prior to addition to the aerosol flow reactor by passing the $\mathrm{O}_{2}$ flow

137 through a small cell with a quartz window adjacent to a $\mathrm{Hg}$ pen lamp.

138 A series of particle production experiments was performed using varying ratios of the

139 three precursor vapours present in the reactor. The ratio was controlled experimentally by

140 varying the relative gas flow fractions of the entrained precursor vapours. Whilst vapour

141 pressure data for the Fe and Si liquid precursors has been reported in the literature

142 (Gilbert and Sulzmann, 1974; Alcott et al., 2004 respectively), no such data appears to

143 exist for the solid $\mathrm{Mg}$ precursor. In addition, all experiments were performed at constant

144 lamp irradiance in the flow reactor, corresponding to a calculated photolysis rate $(J)$ of $~$

$1452.0 \times 10^{-4} \mathrm{~s}^{-1}$ for $\mathrm{Fe}(\mathrm{CO})_{5}$ (determined from the wavelength-resolved lamp photon flux

146 and the molecular absorption cross-section - see Saunders and Plane, 2010). No cross-

147 section data is available in the literature for the other precursors. The generated particles

148 were sampled downstream of the flow cell by inertial deposition onto holey-carbon grids

149 (300 mesh Cu, Agar Scientific) suspended in the gas flow, for subsequent TEM (Philips

150 CM200) imaging and quantitative compositional analysis using energy dispersive x-ray

151 (EDX) and electron energy loss techniques.

\section{3. Results \& Discussion}

154 3.1 Electron microscope and elemental analysis

155 Figure 1 is an electron micrograph of a particle aggregate generated by the photo-

156 oxidation of a mixture of the Fe, $\mathrm{Mg}$ and $\mathrm{Si}$ precursors described previously. Whilst the

157 maximum projected length of this structure from the 2D image is in excess of 2 microns, 
158 it is evident that the fractal-like nature of the aggregate is generated from smaller particle

159 clusters made up of constituent 'primary' particles with an observable range of sizes

160 down to $\sim 10 \mathrm{~nm}$. Previous growth modelling analysis of iron oxide and silicate particles

161 generated within the same flow reactor (Saunders and Plane, 2006; 2010) indicate a

162 primary particle size typically between $6-8 \mathrm{~nm}$ for such particles under conditions of

163 room temperature and atmospheric pressure.

164

$165 \rightarrow$ Figure 1

166 Figure 2 shows EDX spectra obtained from particles generated from three different

167 vapour mixtures. The top spectrum was taken from a particle aggregate formed from the

168 photo-oxidation of the iron-silicon system, the middle spectrum from the iron-

169 magnesium-silicon system, and the bottom spectrum from the magnesium-silicon system.

$171 \rightarrow$ Figure 2

172

173 Seven different experiments were performed: one $\mathrm{Fe} / \mathrm{Si}$ run, one $\mathrm{Mg} / \mathrm{Si}$ run, and five

174 separate $\mathrm{Fe} / \mathrm{Mg} / \mathrm{Si}$ runs where the $\mathrm{Fe}$ and $\mathrm{Mg}$ precursor flows were varied. The relative

$175 \mathrm{Fe}, \mathrm{Mg}$ and Si content in the particles was determined using the integrated EDX peak

176 areas and $\mathrm{x}$-ray scattering cross-sections ( $\mathrm{Si}_{\mathrm{K}}, \mathrm{Fe}_{\mathrm{K}, \mathrm{L}}$ and $\mathrm{Mg}_{\mathrm{K}}$ ) (Goodhew et al., 2001).

177 Analysis was typically performed on 5 different regions of each sampled particle (using a

178 probe size of $1 \mathrm{~nm}$ ), and on 5-10 different particles collected in the same experiment. The

179 elemental values obtained in this way were highly consistent, with less than $10 \%$ 
180 variation for a given particle sample in each experiment. It should be noted that we did

181 not observe any particles of purely iron or magnesium oxide composition from these

182 experiments. The relative abundance data was then used to calculate values of $x_{\text {particle }}(=$

$183 \mathrm{Mg} /(\mathrm{Mg}+\mathrm{Fe}))$ for comparison with the olivine and pyroxene stoichiometries $-\left(\mathrm{Mg}_{x} \mathrm{Fe}_{1-}\right.$

$\left.184{ }_{x}\right)_{2} \mathrm{SiO}_{4}$ and $\mathrm{Mg}_{x} \mathrm{Fe}_{1-x} \mathrm{SiO}_{3}$, respectively. These are listed in Table 1 along with the flow

185 rates used for the precursor species, oxidant and bath gas $\left(\mathrm{N}_{2}\right)$.

$187 \rightarrow$ Table 1

189 Figure 3 shows particle $x$ values plotted against the ratio of $(\mathrm{Mg}+\mathrm{Fe}) / \mathrm{Si}$ for each

190 experiment. Within error, the average particle compositions from all experiments are

191 consistent with olivine and not pyroxene structures.

$193 \rightarrow$ Figure 3

195 For further verification of the particle compositions, electron energy loss spectroscopy

196 (EELS) was also conducted in order to quantify the oxygen content $\left(\mathrm{O}_{\mathrm{K}}\right)$. These were

197 plotted as a ratio with respect to $\mathrm{Fe}, \mathrm{Mg}$ and $\mathrm{Si}$ atomic content using the integrated peak

198 areas, as discussed in Saunders and Plane (2006), against the $x_{\text {particle values determined }}$

199 above. Figure 4 indicates that the measured elemental data (coloured points) are in accord

200 with those predicted for olivine structures (solid coloured lines). In addition, as with our

201 earlier study, analysis of the $\mathrm{Fe}_{\mathrm{L} 2,3}$ line structures (van Aken and Liebscher, 2002) 
202 indicated a single $(+2)$ oxidation state. Electron diffraction revealed no diffraction

203 behaviour for any of the particle aggregates analysed at a number of different points and

204 so confirmed that, for all samples, the particles were entirely amorphous.

$206 \rightarrow$ Figure 4

208 The EDX/EELS analysis clearly indicates that particle composition resulting from the

209 photo-oxidation of Fe-, Mg-, and Si-precursor vapours was homogeneous in all cases.

210 From this, it can be concluded that particle nucleation in this system occurs from a

211 homogeneous mix of condensable gas-phase species, the identities of which we will

212 discuss in section 3.2 .

213 If the $\mathrm{Mg}$ and $\mathrm{Fe}$ content in the particles are a fraction $\alpha$ of their respective gas-phase

214 precursor concentrations i.e. $\mathrm{Mg}=\alpha_{\mathrm{Mg}}\left[\mathrm{Mg}\left(\mathrm{OC}_{2} \mathrm{H}_{5}\right)_{2}\right]$ and $\mathrm{Fe}=\alpha_{\mathrm{Fe}}\left[\mathrm{Fe}(\mathrm{CO})_{5}\right]$, then the

215 ratio of $\mathrm{Mg} / \mathrm{Fe}$ in the particle should be

$$
\frac{\mathrm{Mg}}{\mathrm{Fe}}=\frac{\alpha_{\mathrm{Mg}}\left[\mathrm{Mg}\left(\mathrm{OC}_{2} \mathrm{H}_{5}\right)_{2}\right]}{\alpha_{\mathrm{Fe}}\left[\mathrm{Fe}(\mathrm{CO})_{2}\right] 7}
$$

$219 \alpha$ combines the precursor photolysis rate and efficiencies with which the resulting metal

220 oxide and silicate condense. Note that in the case of $\mathrm{Mg}\left(\mathrm{OC}_{2} \mathrm{H}_{5}\right)_{2}$ there does not appear to

221 be published data on its photolysis cross section. 
223 Since

224

$$
x=\frac{\mathrm{Mg}}{\mathrm{Mg}+\mathrm{Fe}}
$$

225 then

$$
\left(\frac{x}{1-x}\right)=\frac{\left.\alpha_{\mathrm{Mg}} \mid \operatorname{Mg}\left(\mathrm{OC}_{2} \mathrm{H}_{5}\right)_{2}^{226}\right]}{\alpha_{\mathrm{Fe}}\left[\mathrm{Fe}(\mathrm{CO})_{52] 27}\right]}
$$

229 Each vapour is entrained in a flow of $\mathrm{N}_{2}$ passing through a reservoir cell containing its

230 respective precursor. Under the slow flow conditions used here, the gas-phase precursor

231 concentrations in the photolysis cell are then linearly proportional to the $\mathrm{N}_{2}$ flows through

232 their respective reservoir cells. Hence, the ratio of the precursor flows, $f(\mathrm{Mg}) / f(\mathrm{Fe})$, can

233 be substituted into eqn. II, yielding

$$
\left(\frac{x}{1-x}\right)=\frac{\beta_{\mathrm{Mg}} f(\mathrm{Mg})}{\beta_{\mathrm{Fe}} f\left(\mathrm{Fe}^{3}\right)}
$$

237 where $\beta$ combines $\alpha$ with the vapour pressure of the respective precursor (data on the

238 vapour pressure of $\mathrm{Mg}\left(\mathrm{OC}_{2} \mathrm{H}_{5}\right)_{2}$ does not appear to be available). Figure 5 is a plot of

$239 x /(1-x)$ against $f(\mathrm{Mg}) / f(\mathrm{Fe})$, which is linear with a slope of $0.096\left(\mathrm{R}^{2}=0.938\right)$.

240 Importantly, this demonstrates that the relative abundance of $\mathrm{Mg}$ to $\mathrm{Fe}$ in the particles has

241 a linear dependence on the relative flows of their precursor vapours, so that particles with

242 a composition anywhere between $x=0$ and 1 can be made in a simple quantitative way. 


\section{$244 \rightarrow$ Figure 5}

246 3.2 Chemical pathways to final particle compositions

247 Photolysis of the precursor vapours produces Fe, $\mathrm{Mg}$ and $\mathrm{Si}$ atoms, and the reaction

248 kinetics of these atoms and their oxides with $\mathrm{O}_{2}$ and $\mathrm{O}_{3}$ have been studied previously in

249 our group (Gómez Martín et al., 2009a; Gómez Martín et al., 2009b; Helmer and Plane,

250 1994a; Rollason and Plane, 2000; 2001). Inspection of the rate coefficients listed in Table

2512 shows that in the large excess of $\mathrm{O}_{2}$ and $\mathrm{O}_{3}$ employed in the present experiments, $\mathrm{Fe}$

252 and $\mathrm{Mg}$ would have been rapidly oxidized to $\mathrm{FeO}_{3}$ and $\mathrm{MgO}_{3}$, and $\mathrm{Si}$ to $\mathrm{SiO}_{2}$

$254 \rightarrow$ Table 2

256 In order to investigate the subsequent steps to particle formation, we now employ

257 electronic structure calculations using the Gaussian 09 suite of programs (Frisch et al.,

258 2009). The hybrid density functional/Hartree-Fock B3LYP method was employed

259 together with the $6-311+\mathrm{G}(2 \mathrm{~d}, \mathrm{p})$ triple zeta basis set, which is a reasonably large, flexible

260 basis set with both polarization and diffuse functions added to the atoms. The expected

261 uncertainty in the calculated reaction enthalpies is $\pm 20 \mathrm{~kJ} \mathrm{~mol}^{-1}$ at this level of theory. For

262 each molecule the geometry was first optimised, and then vibrational frequencies

263 calculated to determine the zero point energy correction. For the Fe-containing species,

264 all possible spin multiplicities were investigated. The most stable isomers (invariably spin

265 high), are reported here. 
266 The present experiments were performed with a small excess of $\mathrm{SiO}_{2}$ over the metal

267 oxides (as in our previous study on $\mathrm{Fe}_{2} \mathrm{SiO}_{4}$ formation (Saunders and Plane, 2006)).

268 Therefore, starting from the feedstock of $\mathrm{MgO}_{3}, \mathrm{FeO}_{3}$ and $\mathrm{SiO}_{2}$ it is likely that the metal

269 silicate molecules $\mathrm{MgSiO}_{3}$ and $\mathrm{FeSiO}_{3}$ first form via the following highly exothermic

270 reactions:

271

272

$\mathrm{MgO}_{3}+\mathrm{SiO}_{2} \rightarrow \mathrm{MgSiO}_{3}+\mathrm{O}_{2}$

$\Delta H^{\mathrm{o}}(0 \mathrm{~K})=-309 \mathrm{~kJ} \mathrm{~mol}^{-1}$

$273 \quad \mathrm{FeO}_{3}+\mathrm{SiO}_{2} \rightarrow \mathrm{FeSiO}_{3}+\mathrm{O}_{2}$

$\Delta H^{\mathrm{o}}(0 \mathrm{~K})=-241 \mathrm{~kJ} \mathrm{\textrm {mol } ^ { - 1 }}$

275 As shown in Figure 6, these silicate molecules have planar kite-shaped geometries (the

276 most stable electronic state of $\mathrm{FeSiO}_{3}$ has quintet spin multiplicity i.e. four parallel

277 unpaired electrons; $\mathrm{MgSiO}_{3}$ is a singlet with no unpaired spins). A distinctive feature of

278 the silicates is that they possess very large electric dipole moments: $\mu\left(\mathrm{MgSiO}_{3}\right)=12.2$

279 Debye and $\mu\left(\mathrm{FeSiO}_{3}\right)=9.5$ Debye. This will favour polymerization of the silicates,

280 which should occur rapidly because of the long-range attractive forces generated between

281 the polar molecules.

282

$283 \longrightarrow$ Figure 6

284

285 Figure 6 illustrates the geometries of the polymers formed between these silicates. The

286 binding energies are extremely large: 


$\begin{array}{lll}288 & \mathrm{MgSiO}_{3}+\mathrm{MgSiO}_{3} \rightarrow\left(\mathrm{MgSiO}_{3}\right)_{2} & \Delta H^{\mathrm{O}}(0 \mathrm{~K})=-446 \mathrm{~kJ} \mathrm{~mol}^{-1} \\ 289 & \mathrm{FeSiO}_{3}+\mathrm{MgSiO}_{3} \rightarrow \mathrm{FeSiO}_{3}-\mathrm{MgSiO}_{3} & \Delta H^{\mathrm{O}}(0 \mathrm{~K})=-396 \mathrm{~kJ} \mathrm{~mol}^{-1} \\ 290 & \mathrm{FeSiO}_{3}+\mathrm{FeSiO}_{3} \rightarrow\left(\mathrm{FeSiO}_{3}\right)_{2} & \Delta H^{\mathrm{O}}(0 \mathrm{~K})=-343 \mathrm{~kJ} \mathrm{~mol}^{-1}\end{array}$

292 Since the enthalpies for the addition of further silicate molecules to an embryonic particle

293 are likely to be similarly large, there is unlikely to be a free energy barrier to spontaneous

294 nucleation and growth.

295 However, the analysis of the particles formed in our experiments shows that they are

296 composed of olivines rather than pyroxenes. There are two likely ways in which this

297 happens. First, olivine molecules may actually form in the gas phase. This is because the

$298 \mathrm{MgSiO}_{3}$ and $\mathrm{FeSiO}_{3}$ molecules are produced in an excess of $\mathrm{MgO}_{3}$ and $\mathrm{FeO}_{3}$, so that the

299 following reactions can occur:

300

$301 \mathrm{MgSiO}_{3}+\mathrm{MgO}_{3} \rightarrow \mathrm{Mg}_{2} \mathrm{SiO}_{4}+\mathrm{O}_{2} \quad \Delta H^{\mathrm{o}}(0 \mathrm{~K})=-252 \mathrm{~kJ} \mathrm{~mol}^{-1}$

$302 \mathrm{MgSiO}_{3}+\mathrm{FeO}_{3} \rightarrow \mathrm{MgFeSiO}_{4}+\mathrm{O}_{2}$

$\Delta H^{\mathrm{o}}(0 \mathrm{~K})=-206 \mathrm{~kJ} \mathrm{~mol}^{-1}$

$303 \mathrm{FeSiO}_{3}+\mathrm{MgO}_{3} \rightarrow \mathrm{MgFeSiO}_{4}+\mathrm{O}_{2}$

$\Delta H^{\mathrm{o}}(0 \mathrm{~K})=-273 \mathrm{~kJ} \mathrm{~mol}{ }^{-1}$

$304 \mathrm{FeSiO}_{3}+\mathrm{FeO}_{3} \rightarrow \mathrm{Fe}_{2} \mathrm{SiO}_{4}+\mathrm{O}_{2}$

$\Delta H^{\mathrm{o}}(0 \mathrm{~K})=-221 \mathrm{~kJ} \mathrm{~mol}^{-1}$ 
306 Once again, all these reactions are very favourable thermodynamically. The olivine

307 molecules, which are illustrated in Figure 7, should also polymerize spontaneously

308 through highly exothermic reactions. For example, for the two dimers shown in Figure 7:

309

310

$\mathrm{Mg}_{2} \mathrm{SiO}_{4}+\mathrm{Mg}_{2} \mathrm{SiO}_{4} \rightarrow\left(\mathrm{Mg}_{2} \mathrm{SiO}_{4}\right)_{2}$

$\Delta H^{\mathrm{o}}(0 \mathrm{~K})=-512 \mathrm{~kJ} \mathrm{~mol}^{-1}$

311

$\mathrm{MgFeSiO}_{4}+\mathrm{MgFeSiO}_{4} \rightarrow\left(\mathrm{MgFeSiO}_{4}\right)_{2} \quad \Delta H^{\mathrm{o}}(0 \mathrm{~K})=-529 \mathrm{~kJ} \mathrm{~mol}^{-}$

313 Figure 7 also shows the $\mathrm{Mg}_{2} \mathrm{SiO}_{4}$ tetramer, formed from the polymerization of two

$314 \quad \mathrm{Mg}_{2} \mathrm{SiO}_{4}$ dimers:

315

$316 \quad\left(\mathrm{Mg}_{2} \mathrm{SiO}_{4}\right)_{2}+\left(\mathrm{Mg}_{2} \mathrm{SiO}_{4}\right)_{2} \rightarrow\left(\mathrm{Mg}_{2} \mathrm{SiO}_{4}\right)_{4} \quad \Delta H^{\mathrm{o}}(0 \mathrm{~K})=-590 \mathrm{~kJ} \mathrm{~mol}^{-1}$

$318 \rightarrow$ Figure 7

320 This process is also extremely exothermic (calculated at the B3LYP/3-21+g level of

321 theory), underlining the strong thermodynamic force behind polymerization of these

322 molecules. Thus there is a plausible route involving reactions 1 and 2 to form the silicate

323 molecules, followed by reaction $6-9$ to form the olivine molecules, which would

324 generate particles with the observed olivine structure where $x$ would be equal to the

325 relative rates of photochemical production of $\mathrm{Mg}$ to $\mathrm{Fe}$ atoms. 
326 Note, however, that this reaction sequence requires reactions $6-9$ to be faster than

327 reactions $3-5$ (where the silicates polymerize directly together). If in fact silicate

328 polymerization is competitive, then the resulting amorphous pyroxene particles must

329 rearrange internally to form olivines. This is the second way in which the observed

330 olivine particles could form. To get a sense of the thermodynamic requirements for

331 structural rearrangement, consider the enthalpies for the following reactions which

332 convert pyroxene to olivine molecules:

333

$334 \mathrm{MgSiO}_{3}+\mathrm{MgSiO}_{3} \rightarrow \mathrm{Mg}_{2} \mathrm{SiO}_{4}+\mathrm{SiO}_{2} \quad \Delta H^{\mathrm{o}}(0 \mathrm{~K})=+57 \mathrm{~kJ} \mathrm{~mol}^{-1}$

$335 \mathrm{MgSiO}_{3}+\mathrm{FeSiO}_{3} \rightarrow \mathrm{MgFeSiO}_{4}+\mathrm{SiO}_{2} \quad \Delta H^{\mathrm{O}}(0 \mathrm{~K})=+36 \mathrm{~kJ} \mathrm{~mol}^{-1}$

$336 \mathrm{FeSiO}_{3}+\mathrm{FeSiO}_{3} \rightarrow \mathrm{Fe}_{2} \mathrm{SiO}_{4}+\mathrm{SiO}_{2} \quad \Delta H^{\mathrm{o}}(0 \mathrm{~K})=+21 \mathrm{~kJ} \mathrm{~mol}^{-1}$

338 The dimerization of $\mathrm{SiO}_{2}$ is strongly exothermic:

$340 \mathrm{SiO}_{2}+\mathrm{SiO}_{2} \rightarrow\left(\mathrm{SiO}_{2}\right)_{2} \quad \Delta H^{\mathrm{O}}(0 \mathrm{~K})=-401 \mathrm{~kJ} \mathrm{~mol}^{-1}$

341 Hence, combining reactions $2 \times(13)+(10)+(16)$ gives:

342

$4 \mathrm{MgSiO}_{3} \rightarrow\left(\mathrm{Mg}_{2} \mathrm{SiO}_{4}\right)_{2}+\left(\mathrm{SiO}_{2}\right)_{2} \quad \Delta H^{\mathrm{o}}(0 \mathrm{~K})=-799 \mathrm{~kJ} \mathrm{~mol}{ }^{-1}$

345 and combining reactions $2 \times(14)+(11)+(16)$ gives: 


$$
2 \mathrm{MgSiO}_{3}+2 \mathrm{FeSiO}_{3} \rightarrow\left(\mathrm{MgFeSiO}_{4}\right)_{2}+\left(\mathrm{SiO}_{2}\right)_{2} \quad \Delta H^{\mathrm{o}}(0 \mathrm{~K})=-858 \mathrm{~kJ} \mathrm{~mol}^{-1}
$$

349 Reactions 17 and 18 are therefore highly exothermic. This indicates that pyroxene might

350 rearrange into olivine in small particles by forming a separate $\mathrm{SiO}_{2}$ phase. Of course, the

351 "separate phases" considered here only consist of dimers of olivine and silica molecules,

352 and further theoretical investigation in this direction would be extremely computer-

353 intensive. We therefore conclude that both direct formation of gas-phase olivine

354 molecules, and possibly some structural rearrangement of condensed silicates, play a role

355 under our experimental conditions.

357 3.3 Comparison with other laboratory studies of Mg-Fe-silicate formation

358 While the present study appears to be the first attempt to investigate the formation of

359 tertiary $\mathrm{Mg}$-Fe-silicate meteoric smoke particles relevant to planetary atmospheres, there

360 have been a number of studies to investigate the formation of metal silicates under the

361 conditions of stellar outflow regions and the ISM. Replicating the conditions -

362 temperatures, pressures and timescales - of these environments in the laboratory is

363 challenging (Nuth et al., 2000). There have been essentially two types of experimental

364 approach. In the first, a sample of olivine, for example, is vaporized by flash heating

365 (Nagahara et al., 1988) or laser ablation (Brucato et al., 2002); the condensation products

366 of the resulting vapours are then collected and analysed. In the second type of

367 experiment, vapours of $\mathrm{Fe}, \mathrm{Mg}$ and $\mathrm{Si}$ are produced in the presence of an oxidant by 
368 decomposition of appropriate precursors, either photochemically (the present study) or in

369 a high temperature $(500-1500 \mathrm{~K})$ thermal reactor (Rietmeijer et al., 1999; Nuth et al.,

370 2000). This second type of experiment is designed to control the molecular "building

371 blocks" of the silicate particles, and here we will compare the results of the

372 photochemical and thermal systems. The experiments of Nuth and co-workers employed

373 the thermal decomposition of $\mathrm{Fe}(\mathrm{CO})_{5}$ and $\mathrm{SiH}_{4}$ in the presence of $\mathrm{O}_{2}$ at a total pressure

374 of around 90 Torr (mostly made up of $\mathrm{H}_{2}$ ). Magnesium atoms were added by vaporizing

$375 \mathrm{Mg}$ metal in a crucible within the thermal reactor. There are therefore two important

376 differences between the photochemical reactor used in the present study and the thermal

377 reactor: the use of $\mathrm{O}_{3}$ versus $\mathrm{O}_{2}$ as the oxidant; and a temperature of $293 \mathrm{~K}$ versus

378 temperatures typically above $1000 \mathrm{~K}$, respectively. A further possibly significant

379 difference is that in the present experiment the three photolytic precursors are well-mixed

380 before entering the photolysis cell, whereas in the thermal reactor there must be some

381 spatial separation between the region where the Fe and Si precursors start to decompose

382 upon entering the hot region of the reactor, and the $\mathrm{Mg}$ vapour is produced from the

383 crucible.

384 The gas-phase chemistry in the two systems is somewhat different. In our photochemical

385 reactor, the building blocks of the metal silicates are $\mathrm{FeO}_{3}, \mathrm{MgO}_{3}$ and $\mathrm{SiO}_{2}$, produced

386 under well-defined kinetic conditions (Section 3.2). In contrast, the chemistry in the

387 thermal reactor is quite complex. The metal dioxides $\mathrm{FeO}_{2}$ and $\mathrm{MgO}_{2}$ will form at the

388 relatively high pressure in the reactor:

389

$$
\mathrm{Fe}+\mathrm{O}_{2}(+\mathrm{M}) \rightarrow \mathrm{FeO}_{2} \quad\left(\mathrm{M}=\text { mainly } \mathrm{H}_{2}\right)
$$

390

$$
\mathrm{Mg}+\mathrm{O}_{2}(+\mathrm{M}) \rightarrow \mathrm{MgO}_{2}
$$


391 Both these reactions have small barriers in their entrance channels so that, unusually for

392 recombination reactions, their rate coefficients increase with temperature (Helmer and

393 Plane, 1994b; Nien et al., 1993). The reactions forming the metal monoxides

$394 \quad \mathrm{Fe}+\mathrm{O}_{2} \rightarrow \mathrm{FeO}+\mathrm{O}$

$$
\mathrm{Mg}+\mathrm{O}_{2} \rightarrow \mathrm{MgO}+\mathrm{O}
$$

are not competitive. The rate of reaction 21 (Akhmadov et al., 1988) only becomes equal

to that of reaction 19 above $1500 \mathrm{~K}$ (at the pressure of the thermal reactor experiment).

398 Although a rate expression for reaction 22 has been published (Kashireninov et al., 1982),

399 this is clearly incorrect because the activation energy of $48 \mathrm{~kJ} \mathrm{~mol}^{-1}$ is much lower than

400 the endothermicity of the reaction, $\Delta H_{0}=246 \mathrm{~kJ} \mathrm{~mol}^{-1}$ (Rollason and Plane, 2001). The

401 upper limit to $k_{22}$ must therefore be extremely small: e.g. $<4 \times 10^{-21} \mathrm{~cm}^{3}$ molecule $\mathrm{s}^{-1}$ at

$4021200 \mathrm{~K}$. SiO will be produced by the decomposition of $\mathrm{SiH}_{4}$ in $\mathrm{O}_{2}$ (Gómez Martin et al.,

403 2009a), but $\mathrm{SiO}_{2}$ may then form via the reaction

$$
\mathrm{SiO}+\mathrm{O}_{2} \rightarrow \mathrm{SiO}_{2}+\mathrm{O}
$$

405 Since reaction 23 is only modestly endothermic $\left(\Delta H_{0}=63 \mathrm{~kJ} \mathrm{~mol}^{-1}\right.$ (Gómez Martín et al., $4062009 b)$ ), it may proceed at a rate similar to reactions 19 and 20 in the thermal reactor.

407 Thus the main building blocks in the thermal reactor are $\mathrm{FeO}_{2}, \mathrm{MgO}_{2}$ and $\mathrm{SiO}$ and/or $408 \quad \mathrm{SiO}_{2}$.

409 A further complication in the thermal reactor is the decomposition of $\mathrm{Fe}(\mathrm{CO})_{5}$ which 410 occurs through sequential loss of $\mathrm{CO}$. A reaction such as

$$
\mathrm{FeCO}+\mathrm{O}_{2} \rightarrow \mathrm{FeO}_{2}+\mathrm{CO}
$$


412 may be very fast, because the reaction is highly exothermic: $\Delta H_{0}=-236 \mathrm{~kJ} \mathrm{~mol}^{-1}$,

413 calculated here at the B3LYP/6-311+g(2d,p) level of theory. Thus formation of Fe

414 silicate particles could occur at temperatures well below $1000 \mathrm{~K}$ once $\mathrm{Fe}(\mathrm{CO})_{5}$ starts to

415 decompose, whereas the Mg silicates cannot not form until reaction 22 becomes fast

416 enough within the hot region of the reactor.

417 It is important to note that in spite of these differences in the molecular building blocks of

418 the two systems, olivine-type particles are produced in both cases. We have shown in

419 Section 3.2 that in the case of the photochemical reactor at low temperatures, the

420 production of olivine particles can be explained by the quenching from the gas phase of

421 molecules of olivine (or pyroxene). So this should be a kinetically controlled system,

422 where the ratio of $\mathrm{Fe}$ to $\mathrm{Mg}$ in the particles is controlled by the relative uptake rates of

423 their respective metal silicate molecules from the gas phase. In the thermal reactor

424 experiments, Nuth et al. (2000) observed the formation of pure magnesium silicate and

425 pure iron silicate amorphous grains above $1000 \mathrm{~K}$. Strikingly, they did not observe any

426 mixed Fe-Mg particles with olivine composition. They attributed this surprising result to

427 the lack of eutectic compositions in the $\mathrm{FeO}-\mathrm{MgO}$ phase diagram (Nuth et al., 2002). In

428 fact, thermodynamic considerations show that the condensation of particles from a Fe-

429 Mg-Si-O mixture under equilibrium conditions above $1000 \mathrm{~K}$ should produce mainly

430 pure forsterite $\left(\mathrm{Mg}_{2} \mathrm{SiO}_{4}\right)$ and some enstatite $\left(\mathrm{MgSiO}_{3}\right)($ Gail and Sedlmayr, 1999).

431 Although the initial polymerization may well be kinetically controlled, reactions such as

$$
\mathrm{Fe}_{2} \mathrm{SiO}_{4(\mathrm{~s})}+2 \mathrm{MgO}_{2(\mathrm{~g})} \rightarrow \mathrm{Mg}_{2} \mathrm{SiO}_{4(\mathrm{~s})}+2 \mathrm{FeO}_{2(\mathrm{~g})}
$$

433 where the $\mathrm{Fe}^{2+}$ ions are displaced by $\mathrm{Mg}$ atoms, are very exothermic $\left(\Delta H=-670 \mathrm{~kJ} \mathrm{~mol}^{-1}\right.$,

434 calculated using $\Delta H=-157 \mathrm{~kJ} \mathrm{~mol}^{-1}$ for the reaction $\mathrm{Fe}_{2} \mathrm{SiO}_{4(\mathrm{~s})}+2 \mathrm{Mg}_{(\mathrm{g})} \rightarrow \mathrm{Mg}_{2} \mathrm{SiO}_{4(\mathrm{~s})}+$ 
$4352 \mathrm{Fe}_{(\mathrm{g})}$ (Gail and Sedlmayr, 1999), and $\Delta H=-256 \mathrm{~kJ} \mathrm{~mol}^{-1}$ for the gas-phase reaction

$436 \mathrm{MgO}_{2}+\mathrm{Fe} \rightarrow \mathrm{FeO}_{2}+\mathrm{Mg}$, calculated at the B3LYP/6-311+g(2d,p) level of theory). Thus

437 the thermal reactor results can be explained by the kinetic formation of mixed silicate

438 particles, subsequent displacement of Fe to form pure $\mathrm{Mg}$ silicates, and finally the

439 formation of Fe silicates once all the magnesium has been removed from the gas phase.

440 In contrast, in the low-temperature photochemistry system the composition of the

441 particles is frozen at the composition determined by the quenching kinetics, so that a

442 single solid phase is produced.

444 4. Implications

445 This new synthetic method for producing amorphous olivine nanoparticles is not

446 supposed to replicate the ambient conditions of either planetary atmospheres or oxygen-

447 rich stellar outflows. Nevertheless, some important conclusions can be drawn regarding

448 the formation of these particles in both types of environment. The rapidity with which the

449 particles form and grow in the laboratory, combined with the results of the electronic

450 structure calculations, suggests that particle formation is a spontaneous process i.e., there

451 are no free energy barriers to nucleation. Indeed, the long-range magnetic dipole forces in

452 Fe-containing particles which drive this rapid growth were explored by us in a previous

453 study (Saunders and Plane, 2006), where we showed that the rates of magnetic dipole-

454 controlled reactions actually get slightly faster at lower temperatures. Hence, particle

455 formation can be expected even at the very low temperatures of the ISM. 
456 The pathway to particle formation in the photochemical reactor - formation of $\mathrm{FeO}_{3}$,

$457 \mathrm{MgO}_{3}$ and $\mathrm{SiO}_{2}$ in the presence of $\mathrm{O}_{3}$ and $\mathrm{O}_{2}-$ is quite probably the route to forming

458 MSPs in the atmospheres of the terrestrial planets. The composition of MSPs in the

459 Earth's atmosphere has been a subject of speculation because their small dimensions both

460 precluded optical detection and also created major difficulties for direct rocket-borne

461 sampling and uncontaminated return from the mesosphere. However, there has been a

462 recent report of detectable particle extinction at two near-IR wavelengths at altitudes

463 above $50 \mathrm{~km}$ made from the AIM satellite (Hervig et al., 2009). Although this extinction

464 is consistent with refractive index data for the pyroxene structure $\mathrm{Mg}_{0.4} \mathrm{Fe}_{0.6} \mathrm{SiO}_{3}$, new

465 work using additional wavelengths in the near-UV and near-IR indicates that the particles

466 have an olivine structure $\mathrm{Mg}_{2 x} \mathrm{Fe}_{2-2 x} \mathrm{SiO}_{4}$, where $x \sim 0.5$ (unpublished data from $\mathrm{M}$.

467 Hervig, presented at the $38^{\text {th }}$ COSPAR General Assembly, Bremen, 2010). This is

468 consistent both with the results of the present study, and with the model prediction that

469 meteoric ablation produces roughly equal quantities of $\mathrm{Fe}, \mathrm{Mg}$ and $\mathrm{Si}$ (Vondrak et al.,

470 2008). However, it should be borne in mind that since the formation of olivine particles

471 requires the condensation of $\mathrm{Fe}$ - and $\mathrm{Mg}$ - containing species with $\mathrm{SiO}_{2}$, and all three are

472 trace species in the upper mesosphere (mixing ratios $<10 \mathrm{ppb}$ ), it is also likely that

473 meteoric vapours produce particles containing oxides such as $\mathrm{Fe}_{2} \mathrm{O}_{3}$ (Saunders and Plane,

474 2010a), and hydroxides and carbonates.

475 Regarding silicate grain formation in the ISM, the relevant precursor species in oxygen-

476 rich circumstellar outflows are thought to be $\mathrm{MgO}, \mathrm{FeO}$ and $\mathrm{SiO} / \mathrm{SiO}_{2}$ (Gail, 2010; Gail

477 and Sedlmayr, 1999; Nuth et al., 2000), which at first glance are different from the

478 species in the photochemical reactor. However, $\mathrm{FeO}_{3}$ and $\mathrm{MgO}_{3}$ have the structures $\mathrm{OFe}$ - 
$479 \mathrm{O}_{2}$ and $\mathrm{OMg}-\mathrm{O}_{2}$ (Rollason and Plane, 2000; 2001), where the weakly-bound $\mathrm{O}_{2}$ acts as a

480 chaperone to the metal oxide. Thus the chemistry in our system may not be very different

481 from that in the ISM. In any case, the fact that olivine-type particles are produced in the

482 photochemical and the thermal reactors (Section 3.3) implies that the precise nature of the

483 metal oxide is secondary.

484 Thermal reactor experiments (Nuth et al., 2000; Rietmeijer et al., 1999) demonstrate that

485 magnesium silicate (forsterite and enstatite) particles are the major product at high

486 temperatures $(>1000 \mathrm{~K})$. This is in accord with observations of a high forsterite

487 abundance in the circumstellar dust shells of stars with high mass loss rates, where

488 nucleation and growth of silicate particles will be faster and thus occur at higher

489 temperatures (de Vries et al., 2010; Nuth et al., 2002). The results of the present study

490 should therefore be applicable to low mass loss rate stars, where condensation will be

491 slow enough that it mostly occurs in cooler regions. Indeed, there is experimental

492 evidence that Fe-rich olivines form at temperatures around $800 \mathrm{~K}$ (Nagahara et al., 1988),

493 which is consistent with the thermodynamic prediction that fayalite and ferrosilite should

494 condense below $900 \mathrm{~K}$ (Gail, 2010). Our experiments were carried out at $293 \mathrm{~K}$ and, as

495 explained above, there is no reason that the condensation of these species will not occur

496 even at very low temperatures. The formation of Fe-rich olivine particles in low mass loss

497 rate environments will have two important consequences. First, because condensation is

498 slower and the concentration of gas-phase species is continuously diluted in the outflow,

499 much smaller particles are likely to result. Second, the particles will almost certainly be

500 amorphous, as observed in the present study at $293 \mathrm{~K}$. Annealing of Mg-Fe-silicates to

501 form crystalline olivines requires temperatures in excess of $1000 \mathrm{~K}$ (Nuth et al., 2002). 


\section{5. Conclusions}

504 This paper describes a photochemical technique for generating amorphous olivine

505 nanoparticles over a controlled composition range. Quantitative compositional analysis of

506 the particles formed by the photo-oxidation of a mixture of $\mathrm{Mg}-\mathrm{Fe}$ - and $\mathrm{Si}$ -

507 organometallic vapours in $\mathrm{O}_{3}$ at room temperature is consistent with a range of olivine

$508\left(\mathrm{Mg}_{2 x} \mathrm{Fe}_{2-2 \mathrm{x}} \mathrm{SiO}_{4}: 0 \leq x \leq 1\right)$ structures. Starting from the known gas-phase chemistry of

$509 \mathrm{Mg}, \mathrm{Fe}$ and $\mathrm{Si}$ atoms in the presence of $\mathrm{O}_{3}$ and $\mathrm{O}_{2}$, which produces $\mathrm{MgO}_{3}, \mathrm{FeO}_{3}$ and

$510 \mathrm{SiO}_{2}$, we have used electronic structure calculations to elucidate the likely pathways to

511 the formation of olivine particles: direct condensation of olivine molecules, and/or the

512 condensation of metal silicates followed by solid-phase structural rearrangement into

513 separate olivine and silica phases.

514 The observed preferential nucleation and growth of amorphous mixed-metal silicate

515 particles from a suitable metal and silicon oxide gas-phase environment, indicates the

516 likely spontaneous formation of such materials in any environment where iron and

517 magnesium oxide molecules are present together with $\mathrm{SiO}_{2}$ i.e. in planetary atmospheres

518 where meteoric ablation occurs, and in cooler regions of the ISM, for example the gas

519 outflows of low mass loss rate oxygen-rich stars.

520 Our photo-oxidation experiments, although not performed under realistic conditions

521 (temperature and pressure) with respect to planetary atmospheres or the ISM, point to an

522 efficient method for the production of nanoparticles of the composition and structure

523 found in these environments. 


\section{Acknowledgements}

526 This work was supported by funding from the UK Natural Environment Research

527 Council (grant NE/E005659/1).

528

529 References

530 Akhmadov, U. S., et al., 1988. Mechanism and kinetics of interaction of Fe, Cr, Mo, and

531 Mn atoms with molecular oxygen. Kinetics and Catalysis 29(2), 251-257.

532 Alcott, G.R., van de Sanden, R.M.C.M., Kondic, S., Linden, J.L., 2004. Vapor pressures

533 of precursors for the CVD of silicon-based films. Chem. Vap. Deposition 10, 20-22.

534 Brucato, J.R., Mennella, V., Colangeli, L., Rotundi, A., Palumbo, P., 2002. Production

535 and processing of silicates in laboratory and in space. Planet. Space Sci. 50, 829-837.

536 Colangeli, L., et al., 2003. The role of laboratory experiments in the characterisation of

537 silicon-based cosmic material. Astron. Astrophys. Rev. 11, 97-152.

538 de Vries, B. L., Min, M., Waters, L.B.F.M., Blommaert, J.A.D.L., Kemper, F., 2010.

539 Determining the forsterite abundance of the dust around asymptotic giant branch stars.

540 Astron. Astrophys. 516, A86, doi: 10.1051/0004-6361/200913588.

541 Dorschner, J., Begemann, B., Henning, Th., Jäger, C., Mutschke, H., 1995. Steps towards

542 interstellar silicate mineralogy. II. Study of Mg-Fe silicate glasses of variable

543 composition. Astron. Astrophys. 300, 503-520. 
544 Draine, B.T., Lee, H.M., 1984. Optical properties of interstellar graphite and silicate

545 grains. ApJ. 285, 89-108.

546 Draine, B.T., 2003. Interstellar dust grains. Annu. Rev. Astron. Astrophys. 41, 241-289.

547 English, M.A., Lara, L.M., Lorenz, R.D., Ratcliff, P.R., Rodrigo, R., 1996. Ablation and

548 chemistry of meteoric materials in the atmosphere of Titan. Adv. Space Res. 17, 157-160.

549 Fast, K.E., et al., 2009. Comparison of HIPWAC and Mars Express SPICAM

550 observations of ozone on Mars 2006-2008 and variation from 1993 IRHS observations.

551 Icarus 203, 20-27.

552 Frisch, M.J., et al., 2009. Gaussian 09, Revision A.1, Gaussian Inc., Wallingford CT.

553 Gail, H.-P., 2010. Formation and evolution of minerals in accretion discs and stellar

554 outflows. Lect. Notes Phys. 815, 61-141.

555 Gail, H.-P., Sedlmayr, E., 1999. Mineral formation in stellar winds. I. Condensation

556 sequence of silicate and iron grains in stationary oxygen rich outflows. Astron.

557 Astrophys. 347, 594-616.

558 Gilbert, A.G., Sulzmann, K.G., 1974. Vapor pressure of iron pentacarbonyl. J.

559 Electrochem. Soc. 121, 832-834.

560 Goodhew, P.J., Humphreys, F.J., Beanland, R., 2001. Electron Microscopy and Analysis,

561 third ed. Taylor \& Francis, London, 243 pp.

562 Gómez-Martín, J.C., Blitz, M.A., Plane, J.M.C., 2009a. Kinetic studies of

563 atmospherically relevant silicon chemistry. Part I: Silicon atom reactions. Phys. Chem.

564 Chem. Phys. 11, 671-678. 
565 Gómez-Martín, J.C., Blitz, M.A., Plane, J.M.C., 2009b. Kinetic studies of

566 atmospherically relevant silicon chemistry. Part II: Silicon monoxide reactions. Phys.

567 Chem. Chem. Phys. 11, 10945-10954.

568 Gorny, S.K., Perea-Calderón, J.V., Garcia-Hernández, D.A., Garcia-Lario, P., Szczerba,

569 R., 2010. New groups of planetary nebulae with peculiar dust chemistry towards the

570 Galactic bulge. Astron. Astrophys. 516, A39, 10.1051/0004-6361/200913010.

571 Helmer, M., Plane, J.M.C., 1994a. Kinetic study of the reaction between Fe and $\mathrm{O}_{3}$ under

572 mesospheric conditions. J. Chem. Soc. Faraday Trans. 90, 31-37.

573 Helmer, M., Plane, J.M.C., 1994b. Experimental and theoretical study of the reaction Fe $574+\mathrm{O}_{2}+\mathrm{N}_{2} \rightarrow \mathrm{FeO}_{2}+\mathrm{N}_{2}$. J. Chem. Soc. Faraday Trans. 90, 395-401.

575 Henning, T., 2010. Cosmic silicates. Annu. Rev. Astron. Astrophys. 48, 21-46.

576 Hervig, M.E., Gordley, L.L., Deaver, L.E., Siskind, D.E., Stevens, M.H., Russell III,

577 J.M., Bailey, S.M., Megner, L., Bardeen, C.G., 2009. First satellite observations of

578 meteoric smoke in the middle atmosphere. Geophys. Res. Lett. 36, L18805,

579 doi:10.1029/2009GL039737.

580 Hörst, S.M., Vuitton, V., Yelle, R.V., 2008. Origin of oxygen species in Titan's

581 atmosphere. J. Geophys. Res. 113, E10006, doi:10.1029/2008JE003135.

582 Hunten, D.M., Turco, R.P., Toon, O.B., 1980. Smoke and dust particles of meteoric 583 origin in the mesosphere and stratosphere. J. Atmos. Sci. 37, 1342-1357.

584 Ip, W.H., 1990. Meteoroid ablation processes in Titan's atmosphere. Nature 345, 511585512. 
586 Jäger, C., Dorschner, J., Mutschke, H., Posch, Th., Henning, Th., 2003. Steps towards

587 interstellar silicate mineralogy. VII. Spectral properties and crystallisation behaviour of

588 magnesium silicates produced by the sol-gel method. Astron. Astrophys. 408, 193-204.

589 Jäger, C., Molster, F.J., Dorschner, J., Henning, Th., Mutschke, H., Waters, L.B.F.M.,

590 1998. Steps towards interstellar silicate mineralogy. IV. The crystalline revolution.

591 Astron. Astrophys. 339, 904-916.

592 Jensen, A.G., Markwick-Kemper, F., Snow, T.P., 2008. Oxygen in the interstellar

593 medium. Rev. Mineral. Geochem. 68, 55-72.

594 Kashireninov, O. E., et al., 1982. Improvement of oxidation kinetic constants of alkali-

595 metal vapors. Zhurnal Fizicheskoi Khimii, 56(4), 1030-1031.

596 Kemper, F., Vriend, W.J., Tielens, A.G.G.M., 2004. The absence of crystalline silicates

597 in the diffuse interstellar medium. ApJ. 609, 826-837.

598 Kim, Y.H., Pesnell, W.D., Grebowsky, J.M., Fox, J.L., 2001. Meteoric ions in the

599 ionosphere of Jupiter. Icarus 150, 261-278.

600 Kimura, Y., Nuth III, J.A., 2007. What is the driving force to form refractory oxide

601 grains? Silicate spectra depend on their formation environment. ApJ. 664, 1253-1263.

602 Kotak, R., et al., 2009. Dust and the type II-plateau supernova 2004ET. ApJ. 704, 306,

603 doi:10.1088/0004-637X/704/1/306

604 Lavvas, P., Yelle, R.V., Vuitton, V., 2009. The detached haze layer in Titan's

605 mesosphere. Icarus 201, 626-633.

606 Li, A., Draine, B.T., 2001. On ultrasmall silicate grains in the diffuse interstellar medium. 607 ApJ. 550, L213-217. 
608 McAuliffe, J.P., Christou, A.A., 2006. Modelling meteor ablation in the venusian

609 atmosphere. Icarus 180, 8-22.

610 Migliorini, A., Piccioni, G., Cardesín Moinelo, A., Drossart, P., 2010. Hydroxyl airglow

611 on Venus in comparison with Earth. Planet. Space Sci. in press.

612 Molina-Cuberos, J.G., López-Moreno, J.J., Arnold, F., 2008. Meteoric layers in planetary

613 atmospheres. Space Sci. Rev. 137, 175-191.

614 Montmessin, F., et al., 2006. Subvisible $\mathrm{CO}_{2}$ ice clouds detected in the mesosphere of

615 Mars. Icarus 183, 403-410.

616 Nagahara, H., Kushiro, I., Mysen, B.O., Mori, H., 1988. Experimental vaporization and

617 condensation of olivine solid solution. Nature 331,516-518.

618 Nien, C. F., Rajasekhar, B., Plane, J.M.C., 1993. Unusual kinetic behaviour of the

619 reactions $\mathrm{Mg}+\mathrm{O}_{2}+\mathrm{M}$ and $\mathrm{Ca}+\mathrm{O}_{2}+\mathrm{M}\left(\mathrm{M}=\mathrm{N}_{2}, \mathrm{He}\right)$ over extended temperature ranges. $\mathrm{J}$.

620 Phys. Chem. 97, 6449-6456.

621 Noll, K.S., Roush, T.L., Cruikshank, D.P., Johnson, R.E., Pendleton, Y.J., 1997.

622 Detection of ozone on Saturn's satellites Rhea and Dione. Nature 388, 45-47.

623 Nuth III, J.A., Hallenbeck, S.L., Rietmeijer, F.J.M., 2000. Laboratory studies of silicate

624 smokes: Analog studies of circumstellar materials. J. Geophys. Res., 105(A5), 10387-

$625 \quad 10396$.

626 Nuth III, J. A., Rietmeijer, F.J.M, Hill, H.G.M., 2002. Condensation processes in

627 astrophysical environments: the composition and structure of cometary grains.

628 Meteoritics Planet. Sci. 37, 1579-1590. 
629 Pesnell, W.D., Grebowsky, J., 2000. Meteoric magnesium ions in the Martian

630 atmosphere. J. Geophys. Res. 105(E1), 1695-1707.

631 Plane, J.M.C., Helmer, M., 1995. Laboratory study of the reactions $\mathrm{Mg}+\mathrm{O}_{3}$ and $\mathrm{MgO}+$

$632 \mathrm{O}_{3}$ : implications for the chemistry of magnesium in the upper atmosphere. Faraday

633 Discuss. 100, 411-430.

634 Rapp, M., Thomas, G.E., 2006. Modeling the microphysics of mesospheric ice particles:

635 Assessment of current capabilities and basic sensitivities. J. Atmos. Sol. Terr. Phys. 68, $636 \quad 715-744$.

637 Rietmeijer, F.J.M., Nuth III, J.A., Karner, J.M., 1999. Metastable eutectic condensation in 638 a Mg-Fe-SiO-H$-\mathrm{H}_{2}-\mathrm{O}_{2}$ vapor: Analogs to circumstellar dust. ApJ. 527, 395-404.

639 Rietmeijer, F.J.M., 2002. The earliest chemical dust evolution in the solar nebula. Chem. 640 Erde. 62, 1-45.

641 Rollason, R.J., Plane, J.M.C., 2000. The reactions of $\mathrm{FeO}$ with $\mathrm{O}_{3}, \mathrm{H}_{2}, \mathrm{H}_{2} \mathrm{O}, \mathrm{O}_{2}$ and $\mathrm{CO}_{2}$. 642 Phys. Chem. Chem. Phys. 2, 2335-2343

643 Rollason, R.J., Plane, J.M.C., 2001. A kinetic study of the reactions of $\mathrm{MgO}$ with $\mathrm{H}_{2} \mathrm{O}$,

$644 \mathrm{CO}_{2}$ and $\mathrm{O}_{2}$ : implications for magnesium chemistry in the mesosphere. Phys. Chem.

645 Chem. Phys. 3, 4733-4740.

646 Rosinski, J., Snow, R.H., 1961. Secondary particulate matter from meteor vapors. J.

647 Meteorol. 18, 736-745.

648 Saunders, R.W., Plane, J.M.C., 2006. A laboratory study of meteor smoke analogues:

649 Composition, optical properties and growth kinetics. J. Atmos. Sol. Terr. Phys. 68, 21826502202. 
651 Saunders, R.W., Plane, J.M.C., 2010. The formation and growth of $\mathrm{Fe}_{2} \mathrm{O}_{3}$ nanoparticles

652 from the photo-oxidation of iron pentacarbonyl. J. Aero. Sci., 41, 475-489.

653 Self, D.E., Plane, J.M.C., 2003. A kinetic study of the reactions of iron oxides and

654 hydroxides relevant to the chemistry of iron in the upper mesosphere. Phys. Chem. Chem.

655 Phys. 5, 1407-1418

656 Thompson, S.P., Evans, A., Jones, A.P., 1996. Structural evolution in thermally

657 processed silicates. Astron. Astrophys. 308, 309-320.

658 Turco, R.P., Toon, O.B., Hamill, P., Whitten, R.C., 1981. Effects of meteoric debris on

659 stratospheric aerosols and gases. J. Geophys. Res. 86(C2), 1113-1128.

660 van Aken, P.A., Liebscher, B., 2002. Quantification of ferrous/ferric ratios in minerals:

661 new evaluation schemes of $\mathrm{Fe}_{23}$ electron energy-loss near-edge spectra. Phys. Chem.

662 Minerals 29, 188-200.

663 Vondrak, T., Plane, J.M.C., Broadley, S., Janches, J., 2008. A chemical model of

664 meteoric ablation. Atmos. Chem. Phys. 8, 7015-7031.

665 Whalley, C.L., Plane, J.M.C., 2010. Meteoric ion layers in the Martian atmosphere

666 Faraday Discuss. in press.

667 Whittet, D.C.B., 2003. Dust in the Galactic Environment, second ed. IOP Publishing,

668 Bristol, $378 \mathrm{pp}$.

669 Williams, D.A., Taylor, S.D., 1996. The chemical role of cosmic dust. Q. J. R. Astr. Soc.

$670 \quad 37,565-592$.

671 Williams, D.A., Hartquist, T.W., 1999. The chemistry of star-forming regions. Acc.

672 Chem. Res. 32, 334-341. 
673 Table 1 Flows $\left(\mathrm{cm}^{3} \mathrm{~min}^{-1}\right.$ at $293 \mathrm{~K}$ and 1 bar) used for the respective precursor vapours

674 (Fe-, $\mathrm{Mg}$ - and $\mathrm{Si}-)$ present in the particle formation experiments. Calculated atomic ratio

$675\left(x_{\text {particle }}=\mathrm{Mg} /(\mathrm{Mg}+\mathrm{Fe})\right)$ from EDX analysis on particles collected from the respective

676 experiments is also shown.

677

\begin{tabular}{|lllllll|}
\hline $\mathbf{F e}$ & $\mathbf{M g}$ & $\mathbf{S i}$ & $\mathbf{O}_{2}$ & $\mathbf{N}_{\mathbf{2}}$ & $\mathbf{M g} / \mathbf{F e}$ & $\boldsymbol{x}_{\text {particle }}$ \\
\hline 15 & 0 & 100 & 40 & 445 & 0 & 0 \\
9 & 20 & 100 & 40 & 429 & 1.82 & 0.11 \\
6 & 40 & 100 & 40 & 411 & 4.44 & 0.36 \\
3 & 50 & 100 & 40 & 404 & 8.33 & 0.47 \\
3 & 75 & 100 & 40 & 382 & 25.0 & 0.65 \\
0 & 100 & 100 & 40 & 357 & 33.33 & 0.78 \\
\hline
\end{tabular}

678

679

680

681

682

683 
684 Table 2 List of the reactions and rate coefficients involved in the oxidation of Fe, to $685 \mathrm{FeO}_{3}, \mathrm{Mg}$ to $\mathrm{MgO}_{3}$, and $\mathrm{Si}$ to $\mathrm{SiO}_{2}$.

\begin{tabular}{|c|c|c|}
\hline Reaction & $k(293 \mathrm{~K})^{\mathrm{a}}$ & Reference \\
\hline $\mathrm{Fe}+\mathrm{O}_{3} \rightarrow \mathrm{FeO}+\mathrm{O}_{2}$ & $2.1 \times 10^{-10}$ & Helmer and Plane, 1994a \\
\hline $\mathrm{Fe}+\mathrm{O}_{2}\left(+\mathrm{N}_{2}\right) \rightarrow \mathrm{FeO}_{2}$ & $1.0 \times 10^{-13}$ & Helmer and Plane, 1994b \\
\hline $\mathrm{FeO}+\mathrm{O}_{3} \rightarrow \mathrm{FeO}_{2}+\mathrm{O}_{2}$ & $1.6 \times 10^{-10}$ & Rollason and Plane, 2000 \\
\hline $\mathrm{FeO}+\mathrm{O}_{2}\left(+\mathrm{N}_{2}\right) \rightarrow \mathrm{FeO}_{3}$ & $9.5 \times 10^{-11}$ & Rollason and Plane, 2000 \\
\hline $\mathrm{FeO}_{2}+\mathrm{O}_{3} \rightarrow \mathrm{FeO}_{3}+\mathrm{O}_{2}$ & $2.5 \times 10^{-10}$ & Self and Plane, 2003 \\
\hline $\mathrm{Mg}+\mathrm{O}_{3} \rightarrow \mathrm{MgO}+\mathrm{O}_{2}$ & $1.4 \times 10^{-10}$ & Plane and Helmer, 1995 \\
\hline $\mathrm{MgO}+\mathrm{O}_{3} \rightarrow \mathrm{MgO}_{2}+\mathrm{O}_{2}$ & $3.4 \times 10^{-11}$ & Plane and Helmer, 1995 \\
\hline $\mathrm{MgO}_{2}+\mathrm{O}_{3} \rightarrow \mathrm{MgO}_{3}+\mathrm{O}_{2}$ & Not measured & See Plane and Helmer, 1995 \\
\hline $\mathrm{Si}+\mathrm{O}_{2} \rightarrow \mathrm{SiO}+\mathrm{O}$ & $0^{-}$ & Gómez-Martín et al., 2009a \\
\hline $\mathrm{Si}+\mathrm{O}_{3} \rightarrow \mathrm{SiO}$ & $4.0 \times 10^{-10}$ & Gómez-Martín et al., 2009a \\
\hline $\mathrm{SiO}+\mathrm{O}_{3} \rightarrow \mathrm{SiO}_{2}+\mathrm{O}_{2}$ & $4.4 \times 10^{-13}$ & Gómez-Martín et al., 2009b \\
\hline
\end{tabular}

${ }^{\mathrm{a}}$ Rate coefficient at $293 \mathrm{~K}$, units: $\mathrm{cm}^{3}$ molecule $\mathrm{s}^{-1}$ 
692

693 Figure 1 Transmission electron micrograph of a typical fractal-like particle aggregate

694 formed from a vapour mixture of $\mathrm{Fe}, \mathrm{Mg}$ and Si precursors.

695 Figure 2 EDX spectra of particles sampled from three particle production experiments in

696 which no Mg precursor vapour was present (top panel), no Fe precursor vapour was

697 present (bottom panel), and in which all three precursor vapours were present in the flow

698 reactor (middle panel). Characteristic element peaks are indicated at the respective

699 electron energy values.

700 Figure 3 Plot of the measured elemental ratio $(\mathrm{Fe}+\mathrm{Mg}) / \mathrm{Si}$ in the sampled particles

701 against $x$, indicating an olivine $\left[\left(\mathrm{Mg}_{x} \mathrm{Fe}_{1-x}\right)_{2} \mathrm{SiO}_{4}\right]$ composition in all cases.

702 Figure 4 Calculated element to oxygen ratios $\mathrm{M}: \mathrm{O}(\mathrm{M}=\mathrm{Fe}$ (black data points), $\mathrm{Mg}$

703 (blue) and Si (red)) from EELS analysis of particles from the same experiments as in Fig.

704 3, plotted against $x$. The solid lines (Fe is black, $\mathrm{Mg}$ is blue, $\mathrm{Si}$ is red) indicate the

705 relationships that would be expected for a pure olivine composition, and the dashed lines

706 those for pyroxene.

707 Figure 5 Correlation plot of the ratio $(f)$ of magnesium to iron precursor vapour flows

708 (Table 1) employed in the respective experiments against calculated atomic ratio $(x=$

$709 \mathrm{Mg} /(\mathrm{Mg}+\mathrm{Fe}))$ in generated mixed silicate particles.

710 Figure 6 Electronic structure calculations at the B3LYP/6-311+g(2d,p) level of theory of

711 the optimised geometries of $\mathrm{MgSiO}_{3}, \mathrm{FeSiO}_{3}$ and their dimers and mixed polymer. 
712 Figure 7 Electronic structure calculations of the optimised geometries of $\mathrm{Mg}_{2} \mathrm{SiO}_{4}$,

$713 \mathrm{MgFeSiO}_{4}$ and $\mathrm{Fe}_{2} \mathrm{SiO}_{4}$; the dimers of $\mathrm{Mg}_{2} \mathrm{SiO}_{4}$ and $\mathrm{MgFeSiO}_{4}$; and the $\mathrm{Mg}_{2} \mathrm{SiO}_{4}$

714 tetramer.

715

716 


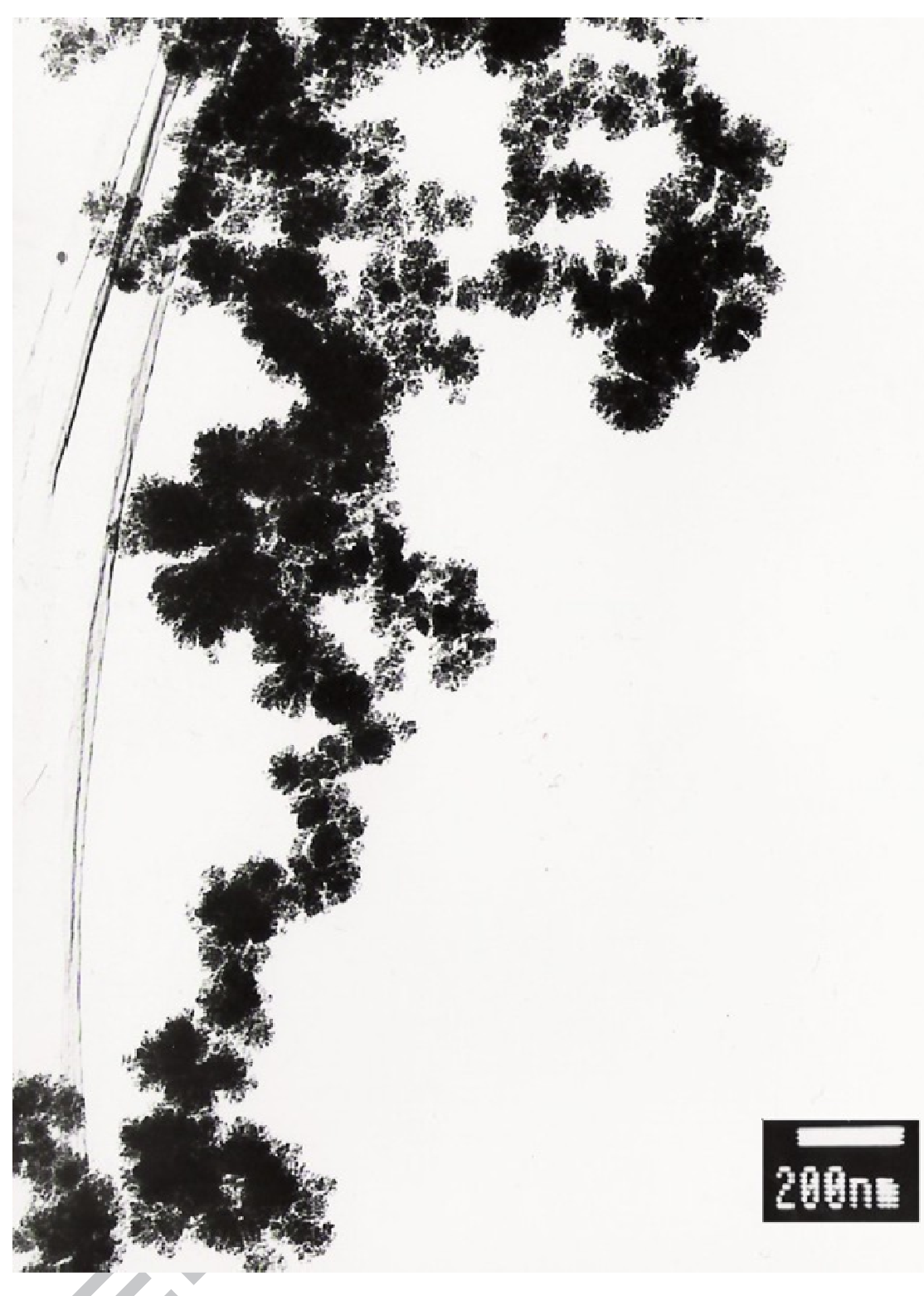



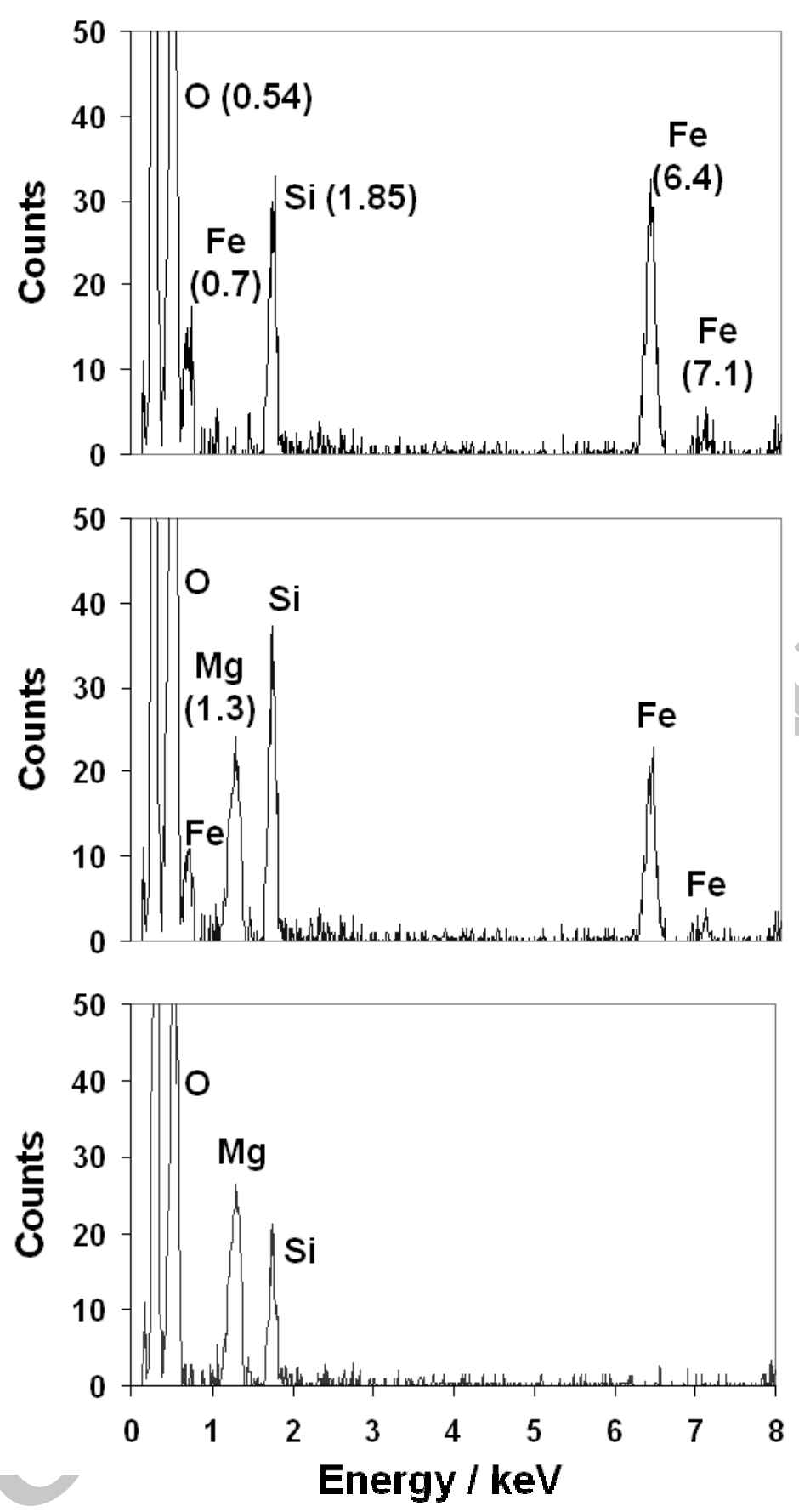


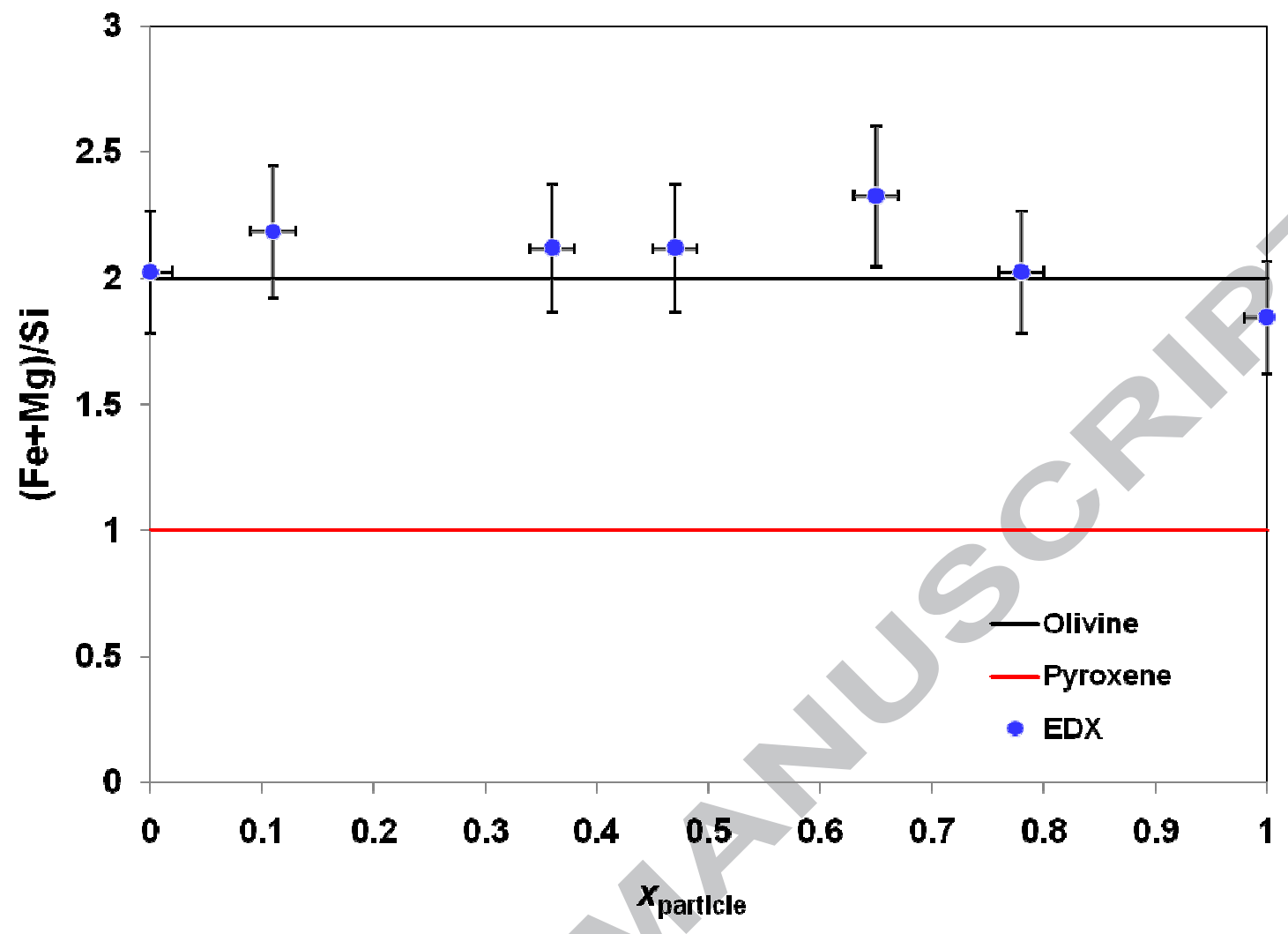




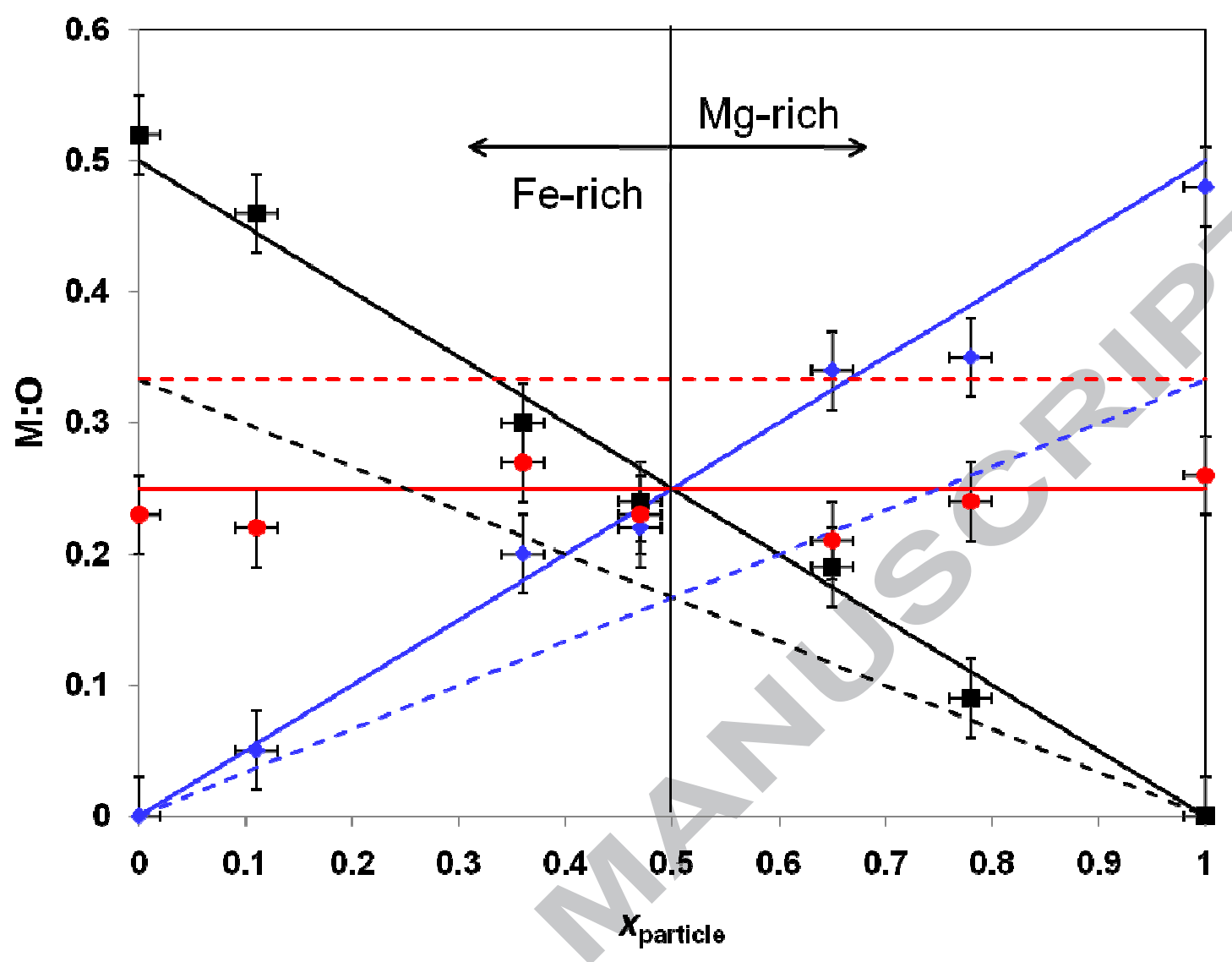

719 


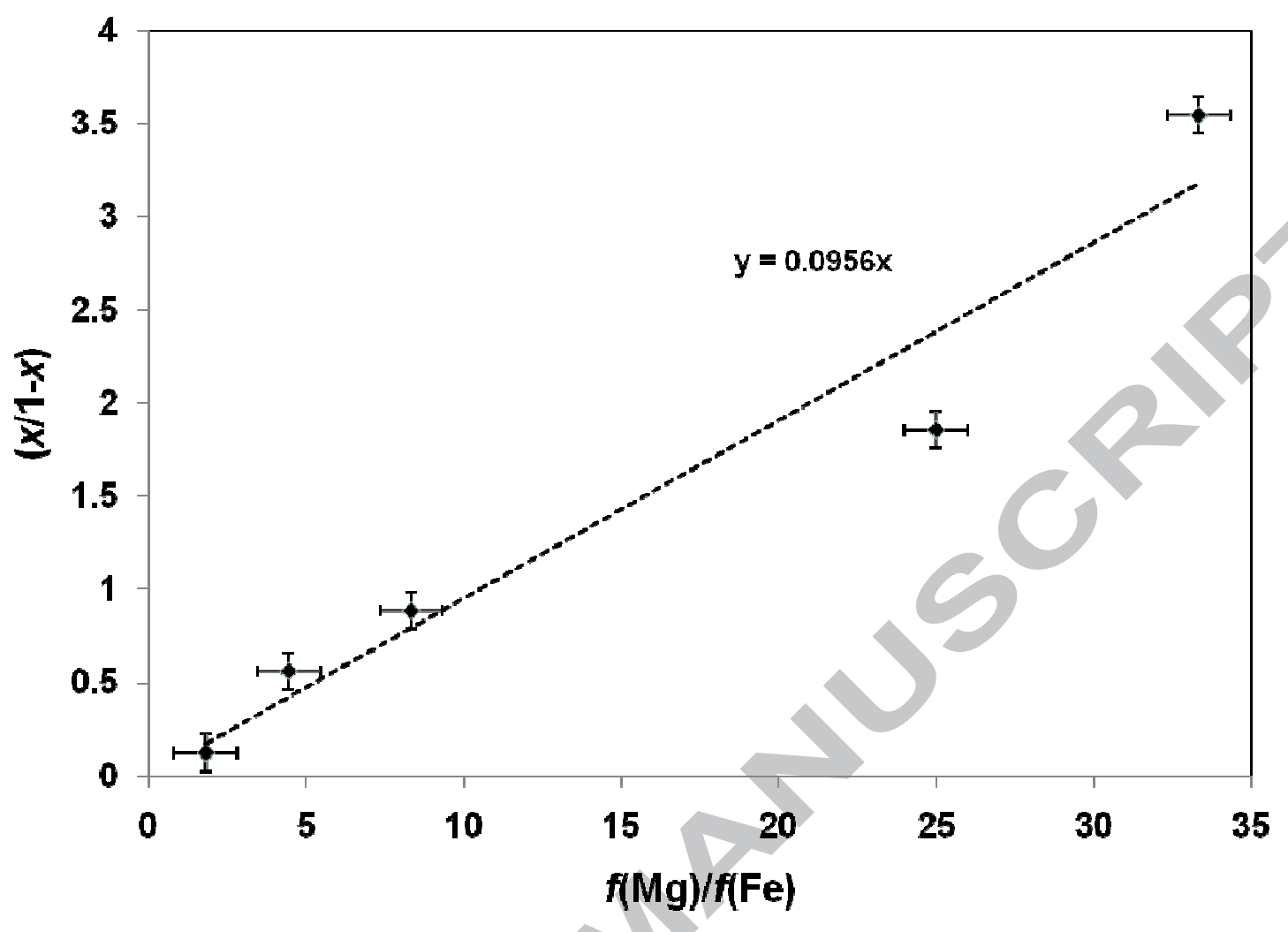

720 


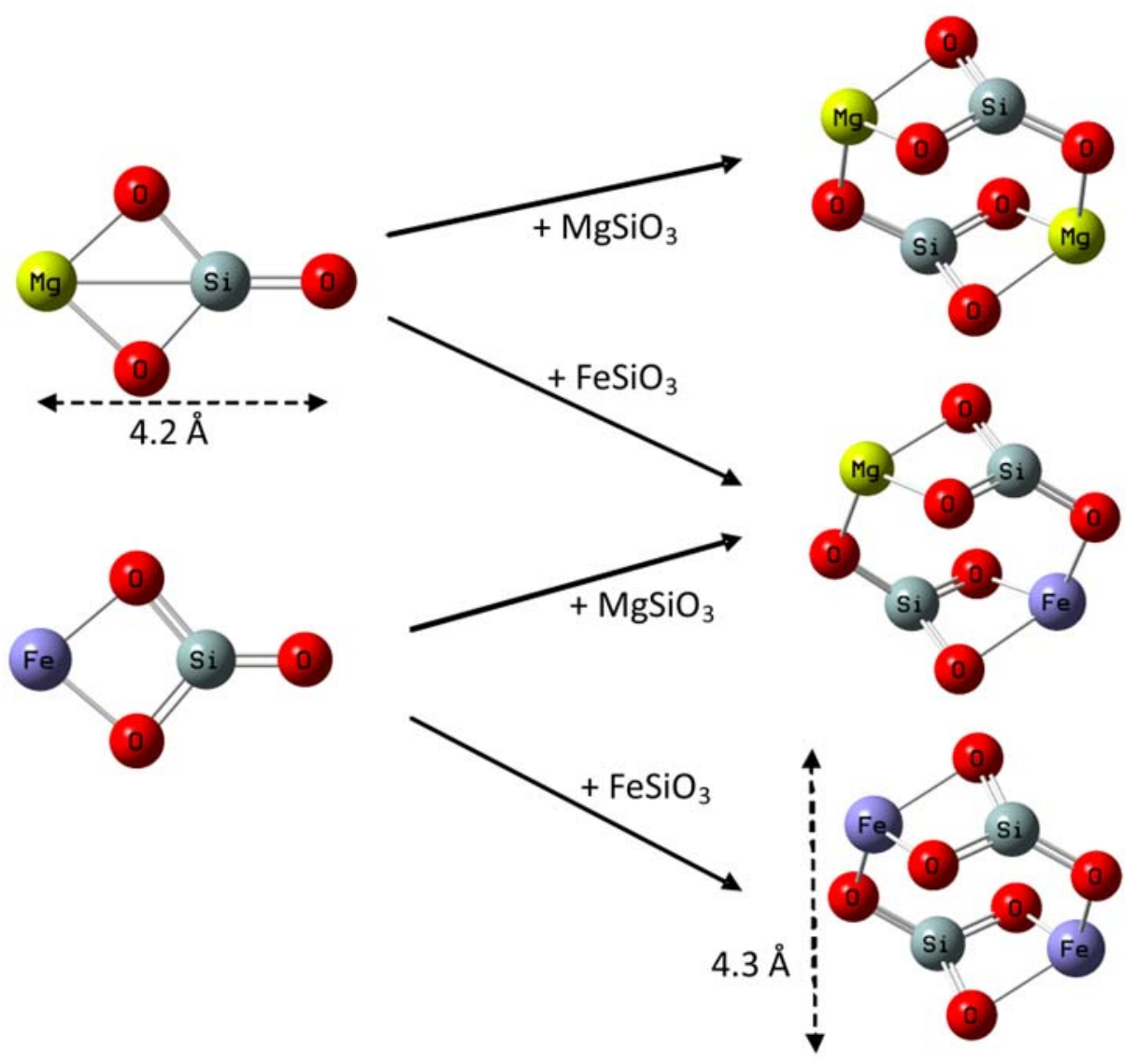

721 

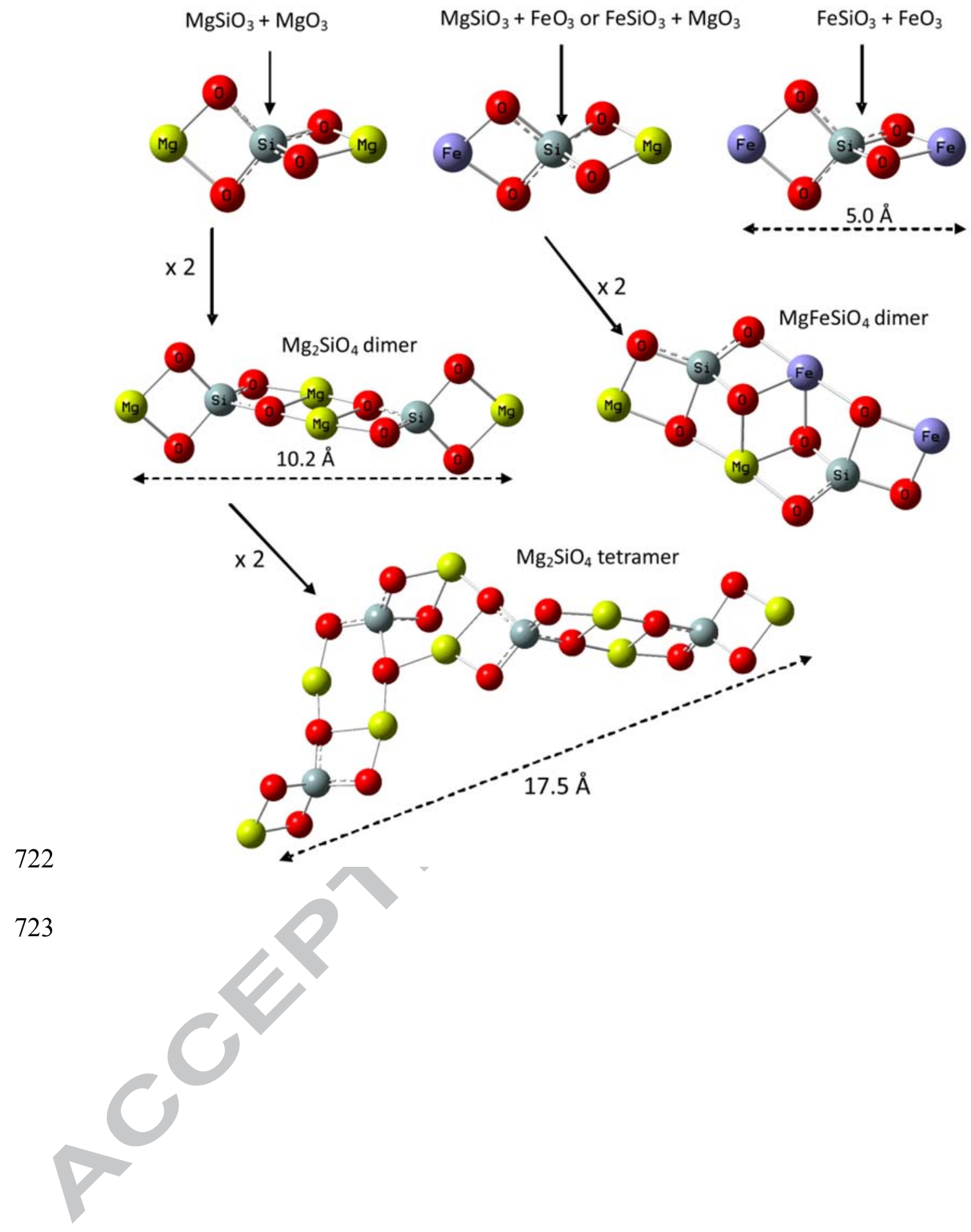

$\mathrm{MgFeSiO}_{4}$ dimer

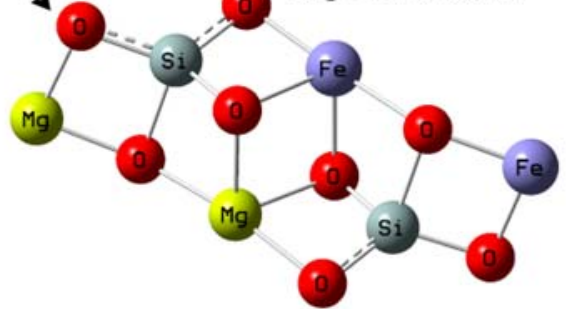

